\title{
Suppression of LH-RH-induced ovulation in hamsters and rats by synthetic analogues of $\mathrm{LH}-\mathrm{RH}^{*}$
}

\author{
N. Nishi, D. H. Coy, E. J. Coy, A. Arimura and A. V. Schally \\ Department of Medicine, Tulane University School of Medicine, and Endocrine and Polypeptide \\ Laboratories, Veterans Administration Hospital, New Orleans, Louisiana 70112, U.S.A.
}

\begin{abstract}
Summary. Peptide antagonists of LH-RH, [D-Phe $\left.{ }^{2}, \mathrm{D}-\mathrm{Phe}^{6}\right]-\mathrm{LH}-\mathrm{RH},\left[\mathrm{D}-\mathrm{Phe}^{2}, \mathrm{D}-\mathrm{Leu}^{6}\right]-$ LH-RH, [D-Phe ${ }^{2}, \mathrm{D}-\mathrm{Ala}^{6}$ ]-LH-RH, [D-Phe ${ }^{2}, \mathrm{Phe}^{3}, \mathrm{D}-\mathrm{Phe}^{6}$ ]-LH-RH, [DesHis $\left.{ }^{2}, \mathrm{D}-\mathrm{Leu}^{6}\right]-$ LH-RH, and [DesHis $\left.{ }^{2}, \mathrm{D}-\mathrm{Phe}^{6}\right]-\mathrm{LH}-\mathrm{RH}$, were examined for their ability to suppress LH-RH-induced ovulation in phenobarbital-blocked hamsters and Nembutal-blocked rats. All of these peptides, with the exception of [DesHis $\left.{ }^{2}, \mathrm{D}-\mathrm{Phe}^{6}\right]-\mathrm{LH}-\mathrm{RH}$ suppressed ovulation to various degrees, but also exhibited various degrees of agonistic activities. Complete suppression of ovulation was achieved in rats with $3 \mathrm{mg}\left[\mathrm{D}-\mathrm{Phe}^{2}, \mathrm{Phe}^{3}\right.$,D-Phe ${ }^{6}$ - LH-RH given in 4 divided doses at 30-min intervals starting $2 \mathrm{hr}$ before the LH-RH injection. It was found that LH levels had to be lower than $5 \mathrm{ng} / \mathrm{ml}$ (control: $20.9 \mathrm{ng} / \mathrm{ml}$ ) to suppress ovulation. However, the extent of suppression of ovulation did not correlate with the serum LH levels $<5 \mathrm{ng} / \mathrm{ml}$. The incidence of ovulation induced by the intrinsic LH-RH activity of some of these analogues was similar to or greater than that resulting from administration of LH-RH plus analogue, suggesting that the activity of LH-RH itself was eliminated by pretreatment with the analogues.
\end{abstract}

\section{Introduction}

Many attempts have been made to produce analogues of LH-RH which are able to bind to pituitary receptor sites but are devoid of gonadotrophin-releasing activity. Such analogues would compete with endogenous LH-RH, preventing its action, and, might, therefore, provide a new means of contraception. Several analogues based on the original decapeptide sequence have been synthesized and found to have weak but significant inhibitory properties (Vilchez-Martinez et al., 1974a). However, it was the discovery of several agonistic analogues of LH-RH that were far more potent than the natural hormone that enabled a variety of relatively strongly active antagonistic peptides to be developed with structures based on the super-active analogues (Coy et al., 1973, 1974; VilchezMartinez et al., 1974b; de la Cruz et al., 1975, 1976a; Corbin \& Beattie, 1975). Most of these analogues, however, possess residual inherent LH-RH activities, which may overcome their LH releaseinhibiting activities, resulting only in partial blockade or no blockade of ovulation in animals. In the present study, an attempt was made, by examining effects on LH-RH-induced ovulation in rats and hamsters under a variety of conditions, to explore the most effective ways of administering some of these compounds to maximize their anti-ovulatory activity and minimize their inherent LH-RH activity.

\section{Materials and Methods}

Analogues. The synthetic analogues of LH-RH that were tested were as follows: Peptide 1 $=\left[\mathrm{D}-\mathrm{Phe}^{2}, \mathrm{D}-\mathrm{Phe}^{6}\right]-\mathrm{LH}-\mathrm{RH} ;$ Peptide $2=\left[\mathrm{D}-\mathrm{Phe}^{2}, \mathrm{D}-\mathrm{Leu}^{6}\right]-\mathrm{LH}-\mathrm{RH} ;$ Peptide $3=\left[\mathrm{D}-\mathrm{Phe}^{2}, \mathrm{D}-\mathrm{Ala}^{6}\right]-$ LH-RH; Peptide $4=\left[\mathrm{D}-\mathrm{Phe}^{2}, \mathrm{Phe}^{3}{ }^{\mathrm{D}}-\mathrm{Phe}^{6}\right]-\mathrm{LH}-\mathrm{RH} ;$ Peptide $5=\left[\mathrm{DesHis}^{2}, \mathrm{D}-\mathrm{Leu}^{6}\right]-\mathrm{LH}-\mathrm{RH}$; Peptide $6=\left[\mathrm{DesHis}^{2}, \mathrm{D}-\mathrm{Phe}^{6}\right]-\mathrm{LH}-\mathrm{RH}$. These analogues were synthesized as reported elsewhere (Vilchez-Martinez et al., 1974a, b; Coy et al., 1973, 1974). They were dissolved in about $100 \mu l$

\footnotetext{
* Reprint requests should be addressed to Dr A.V. Schally.
} 
propylene glycol and then diluted with $0.9 \%(\mathrm{w} / \mathrm{v}) \mathrm{NaCl}$ to give an appropriate concentration (Vehicle 1). Some of the peptides were dissolved in $150 \mu$ benzyl alcohol : ethanol $(2: 1 \mathrm{v} / \mathrm{v})$ and then diluted with sesame oil (Vehicle 2). Each animal received $0.2 \mathrm{ml}$ of this solution for a small dose or $1 \mathrm{ml}$ for a large dose, since some analogues were not very soluble.

Golden hamsters (Lake View Hamsters Colony) and adult female rats (Charles River CD strain) were used throughout the study. They were maintained in an animal house equipped with controlled temperature and illumination (14 hr light from 05.00 to 19.00 hours) and were given free access to Purina laboratory chow and tap water.

Hamsters. The animals were examined every morning for a vaginal discharge as described by Ward (1946) and only animals exhibiting at least 2 consecutive 4-day oestrous cycles were used. At 12.30 hours on the day of pro-oestrus, hamsters were injected s.c. with $13 \mathrm{mg}$ phenobarbital $/ 100 \mathrm{~g}$ body weight to block the spontaneous ovulation. The LH-RH analogues were injected s.c. at various times before s.c. injection of $75 \mathrm{ng} \mathrm{LH}-\mathrm{RH}$ (Takeda TAP-023) which was the minimal effective dose for inducing full ovulation. Peptides 1,2, and 4 were tested for anti-ovulatory activity and the ratio of analogue to LH-RH was $1200: 1$ by weight. The analogues were injected in a single dose of $90 \mu \mathrm{g}$ or as 4 divided equal or stepwise-increasing $(6,12,24$ and $48 \mu \mathrm{g})$ doses. The animals were killed the next morning and their oviducts were inspected for the presence of ova.

Rats. Vaginal smears were checked every morning as described by Everett (1964) and only rats exhibiting at least 2 consecutive 4-day oestrous cycles were selected. On the day of pro-oestrus, the rats were anaesthetized with an i.p. injection of $3.5 \mathrm{mg} \mathrm{Nembutal} / 100 \mathrm{~g}$ body weight at 12.30 hours, and LH-RH was injected s.c. at 14.00 hours. LH-RH analogues were dissolved in Vehicle 1 and administered s.c. at various times before the injection of $150 \mathrm{ng} \mathrm{LH}-\mathrm{RH}$ which was the minimal effective dose for full ovulation. Blood was collected from the jugular vein 30 min after LH-RH treatment, and serum was separated by centrifugation and kept at $-20^{\circ} \mathrm{C}$ until assayed for LH. Animals were killed the next morning and the oviducts were examined for the presence of ova.

LH assay. LH levels were determined in duplicate serum samples by radioimmunoassay as described by Niswender, Midgley, Monroe \& Reichert (1968) using rabbit anti-ovine LH serum (GDN No. 15); NIH-LH-S17 was used as the standard reference preparation. Radioimmunoassay data were analysed by a programme described by Duddleson, Midgley \& Niswender (1972). Coefficients of within-assay variation were $7.5 \%$ and $3.7 \mathrm{ng} / \mathrm{ml}$ and $3.8 \%$ and $2.0 \mathrm{ng} / \mathrm{ml}$. The sensitivity derived from the median variance ratio was $0.15 \mathrm{ng}$. Between-assay variance was $17 \cdot 8 \%$ and $10 \cdot 7$ $\mathrm{ng} / \mathrm{ml}$ in 7 assays.

Statistical analysis. Ovulation response was expressed by binomial data such as 1 for ovulation and 0 for non-ovulation, and these binomial data were subjected to analysis of variance (Hsu \& Feldt, 1969; Seeger \& Gabrielson, 1968) and then to Duncan's new multiple range test (NMR test) (Steel \& Torrie, 1960). The data of the hamster experiment (Table 1) and the second experiment with rats (Table 3) were subjected to one-way analysis of variance, and of the first experiment with rats (Table 2) to two-way analysis of variance. The mean \pm S.E.M. number of eggs ovulated by the rats in each group was calculated and compared with the others using the NMR test. The significance of differences among mean LH levels was also determined by using Duncan's NMR test.

\section{Results}

\section{Hamster experiments}

The anti-ovulatory effects of Peptides 1, 2 and 4 in golden hamsters are shown by the results in Table 1. Analysis of variance indicated that the effect of treatments was highly significant $(P<0 \cdot 01)$. Peptide 1 in Vehicle 1 (Group 2) did not exhibit any intrinsic ovulation-inducing activity and only one hamster in each of Groups 4 and 7 failed to ovulate when LH-RH was also given, indicating that this analogue had an insignificant suppressive effect.

Peptide 2 did not show any intrinsic ovulation-inducing activity in Vehicle 1 (Group 8), but some activity was found with Vehicle 2 (Group 9). Significant suppression of ovulation occurred when the analogue, in either vehicle, was injected $60 \mathrm{~min}$ before LH-RH was given. 
Table 1. Blockade of LH-RH-induced ovulation in phenobarbital-blocked pro-oestrous hamsters by three analogues

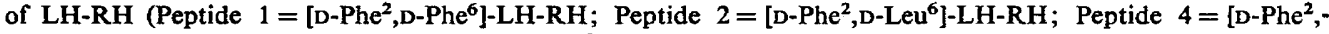
$\mathrm{Phe}^{3}$,D-Phe $]$-LH-RH)

\begin{tabular}{|c|c|c|c|c|c|}
\hline Group & $\begin{array}{c}\text { Dose of } \\
\text { peptide }(\mu \mathrm{g})\end{array}$ & Vehicle & $\begin{array}{c}\text { Time of injection } \\
\text { (min before LH-RH) }\end{array}$ & $\begin{array}{c}\text { No. of ova } \\
\text { (mean } \pm \text { S.E.M.) }\end{array}$ & $\begin{array}{l}\text { No. of animals ovulating/ } \\
\text { No. of animals tested }\end{array}$ \\
\hline \multicolumn{6}{|l|}{ Control } \\
\hline 1 & - & 1 or 2 & 60 or 120 & $12.6 \pm 0.6$ & $15 / 15$ \\
\hline \multicolumn{6}{|l|}{ Peptide 1} \\
\hline 2 & 90 & 1 & - & 0 & $0 / 4^{*}$ \\
\hline 3 & 90 & 1 & 30 & $12 \cdot 2 \pm 0.6$ & $6 / 6$ \\
\hline 4 & 90 & 1 & 60 & $11 \cdot 5 \pm 2 \cdot 3$ & $4 / 5$ \\
\hline 5 & 90 & 2 & 60 & $12 \cdot 0 \pm 1 \cdot 1$ & $4 / 4$ \\
\hline 6 & 90 & 2 & 120 & $14 \cdot 3 \pm 3 \cdot 1$ & $5 / 5$ \\
\hline 7 & 90 & 1 & $120,90,60,30 \ddagger$ & $12.3 \pm 0.9$ & $3 / 4$ \\
\hline \multicolumn{6}{|l|}{ Peptide 2} \\
\hline 8 & 90 & 1 & - & $\mathbf{0}$ & $0 / 4^{*}$ \\
\hline 9 & 90 & 2 & - & $12 \cdot 0$ & $1 / 4^{*}$ \\
\hline 10 & 90 & 1 & 60 & $3 \cdot 6^{*} \pm 2 \cdot 2$ & $2 / 4^{*}$ \\
\hline 11 & 90 & 2 & 60 & $12.5 \pm 0.5$ & $2 / 4^{*}$ \\
\hline 12 & 90 & 2 & 120 & $14.7 \pm 1.3$ & $3 / 3$ \\
\hline 13 & 90 & 1 & $120,90,60,30 \ddagger$ & $10 \cdot 6 \pm 1 \cdot 1$ & $5 / 5$ \\
\hline \multicolumn{6}{|l|}{ Peptide 4} \\
\hline 14 & 90 & 1 & - & 0 & $0 / 5^{*}$ \\
\hline 15 & 90 & 1 & 60 & $11.0 \pm 1.2$ & $5 / 5$ \\
\hline 16 & 90 & 1 & 60 & $10 \cdot 5 \pm 2 \cdot 0$ & $4 / 4$ \\
\hline 17 & 90 & 1 & $120,90,60,30 \dagger$ & $7.5 \pm 0.5$ & $4 / 4$ \\
\hline 18 & 90 & 1 & $120,90,60,30 \ddagger$ & $9.4 \pm 0.7$ & $5 / 5$ \\
\hline
\end{tabular}

$* P<0.05$, when compared with the corresponding value for Group 1 by Duncan's NMR test.

$\dagger$ Stepwise increasing doses.

$\ddagger 4$ injections of equally divided doses.

Peptide 4 in Vehicle 1 (Group 14) did not induce ovulation, but all animals ovulated in the other groups. Hamsters which received divided equal or stepwise-increased doses of LH-RH ovulated fewer eggs, but the decrease was not significant.

\section{Rat experiments}

The ratio of analogue ( $400 \mu \mathrm{g}$ in Vehicle 1) to $\mathrm{LH}-\mathrm{RH}$ was $2666: 1$ and the results with rats in which ovulation was blocked by Nembutal are shown in Table 2 . Analysis of variance indicated that the interaction between LH-RH and analogue was significant $(P<0.002)$. All the analogues tested, Peptides 1, 2 and 5, showed some intrinsic ovulation-inducing activity in this test. Some suppression of LH-RH-induced ovulation was seen, but only the effect of Peptide 1 was significant. There were no differences in the mean numbers of eggs ovulated.

In the experiments in which Peptides 2, 3, 4 and 6 were tested (Table 3), the analogue :LH-RH ratio changed from 6666 to 33,330 . Analysis of variance indicated that the effect of treatments was significant $(P<0.01)$. Since Peptide 4 possessed strong antagonistic but little agonistic activity, as observed in other experiments in which serum LH levels after injection of the analogue were measured, this compound was tested for anti-ovulatory activity under a wide variety of conditions. At a high dose Peptide 4 possessed slight ovulation-inducing activity (Group $3 \mathrm{cf}$. Group 9). The greatest suppression of ovulation was achieved by injecting 2 or $3 \mathrm{mg}$ analogue in 4 equally divided doses (Groups 10-12). If the animals were not bled after LH-RH injection for LH determination (Group 10), the blockade was complete. Bleeding could enhance the ovulation-inducing activity of LH-RH or the analogue as reported by Seyler \& Reichlin (1973). The serum LH values were not (except for those of Group 4) different from those in control Nembutal-blocked rats (Group 2), and there was no correlation between the LH levels and the anti-ovulatory activity of the analogue. 
Table 2. Blockade of LH-RH-induced ovulation in Nembutal-blocked pro-oestrous rats by three analogues of LH-RH (Peptide $2=\left[\mathrm{D}-\right.$ Phe $^{2}$,D-Leu $\left.{ }^{6}\right]-$ LH-RH; Peptide $5=\left[\right.$ DesHis $^{2}$,D-Leu $]-$ LH-RH; Peptide $1=\left[\mathrm{D}-\right.$ Phe ${ }^{2}$,D-Phe ${ }^{6}$-LH-RH)

\begin{tabular}{|c|c|c|c|c|c|}
\hline Group & $\begin{array}{c}\text { Dose of } \\
\text { peptide }(\mu \mathrm{g})\end{array}$ & $\begin{array}{c}\text { Dose of } \\
\text { LH-RH (ng) }\end{array}$ & $\begin{array}{l}\text { Time of injection } \\
\text { (min before LH-RH) }\end{array}$ & $\begin{array}{c}\text { No. of ova } \\
\text { (mean } \pm \text { S.E.M.) }\end{array}$ & $\begin{array}{l}\text { No. of animals ovulating } \\
\text { No. of animals tested }\end{array}$ \\
\hline \multicolumn{6}{|c|}{ Vehicle control } \\
\hline 1 & - & - & - & 0 & $0 / 6$ \\
\hline 2 & - & 150 & 30 & $13 \cdot 7 \pm 0 \cdot 8$ & $6 / 6$ \\
\hline \multicolumn{6}{|l|}{ Peptide 2} \\
\hline 3 & 400 & - & - & $11 \cdot 0 \pm 1 \cdot 5$ & $3 / 4$ \\
\hline 4 & 400 & 150 & 30 & $11 \cdot 3 \pm 1 \cdot 3$ & $3 / 5$ \\
\hline \multicolumn{6}{|l|}{ Peptide 5} \\
\hline 5 & 400 & - & - & $9 \cdot 0 \pm 2 \cdot 3$ & $3 / 4$ \\
\hline 6 & 400 & 150 & 30 & $10.8 \pm 0.7$ & $5 / 10$ \\
\hline \multicolumn{6}{|l|}{ Peptide 1} \\
\hline 7 & 400 & - & - & $13.0 \pm 0.6$ & $3 / 4$ \\
\hline 8 & 400 & 150 & 30 & $10.0 \pm 1.2$ & $3 / 8^{*}$ \\
\hline
\end{tabular}

* Significantly different from value in Group $2, P<0.05$.

A single dose of $5 \mathrm{mg}$ Peptide 4 injected $15 \mathrm{~min}$ before LH-RH (Group 4) suppressed serum LH levels moderately but failed to block ovulation. The same dose and timing of Peptide 3 blocked ovulation in 4 out of 5 rats injected, and suppressed serum LH levels considerably. The $5 \mathrm{mg}$ dose of Peptides 2 or 6 suppressed serum LH levels but not ovulation.

\section{Discussion}

All the LH-RH analogues tested possess anti-ovulatory activities to various degrees, as shown by their suppressive effect on LH-RH-induced ovulation in phenobarbital-blocked hamsters and/or Nembutal-blocked rats. All of these analogues lack His or have D-Phe at position 2 and a D-amino acid at position 6. In addition, one analogue (Peptide 5) had Phe in place of Trp in position 3.

The anti-ovulatory activities of these analogues varied according to the time of administration in relation to the time of injection of LH-RH, thus agreeing with the observations of Vilchez-Martinez et al. $(1974 \mathrm{a}, \mathrm{b})$ that the peak antagonist activities of these analogues in immature male rats varied from $30 \mathrm{~min}$ to $120 \mathrm{~min}$. When dissolved in Vehicle 1 and injected $60 \mathrm{~min}$ before LH-RH, Peptide 2 exhibited greater anti-ovulatory activity in hamsters than Peptides 1 or 4 . In rats, $5 \mathrm{mg}$ Peptide 3 injected $15 \mathrm{~min}$ before LH-RH showed greater anti-ovulatory activity than the same dose of Peptide 2 or 4 given at the same time. On the other hand, Peptide 4 exhibited greater anti-ovulatory activity when injected $90 \mathrm{~min}$ before LH-RH or given in 4 divided doses starting $120 \mathrm{~min}$ before LH-RH. This may indicate that Peptide 3 acts on the pituitary more quickly than Peptide 4. Since Peptides 1 and 4 are hydrophobic, the delayed absorption and probably gradual increase in serum levels of these compounds could account for the delayed action. The insignificant action of $90 \mu \mathrm{g}$ of either of these two peptides in hamsters might also be due to slow absorption resulting in serum levels insufficient to block the action of LH-RH. As revealed in the experiments with rats, an analogue: $\mathrm{LH}-\mathrm{RH}$ ratio of $2700: 1$ or greater appears to be necessary for these rather hydrophobic peptides to exercise a significant anti-ovulatory action. Although our results do not clearly show that the divided doses of Peptide 4 exert greater antagonistic activity and smaller agonistic activity, de la Cruz et al. (1975) observed that 3 s.c. injections of $1 \mathrm{mg}$ Peptide 4 into pro-oestrous rats completely blocked spontaneous ovulation, while the anti-ovulatory effect of a single injection of $1.0-1.5 \mathrm{mg}$ of this antagonist was incomplete. These authors also found that Peptide 2 in 4 separate doses suppressed the preovulatory surge of LH in hamsters. Peptide 4 does, however, produce significant suppression of the preovulatory LH surge, which otherwise lasts for several hours, and blockade of spontaneous as well as induced ovulation. 


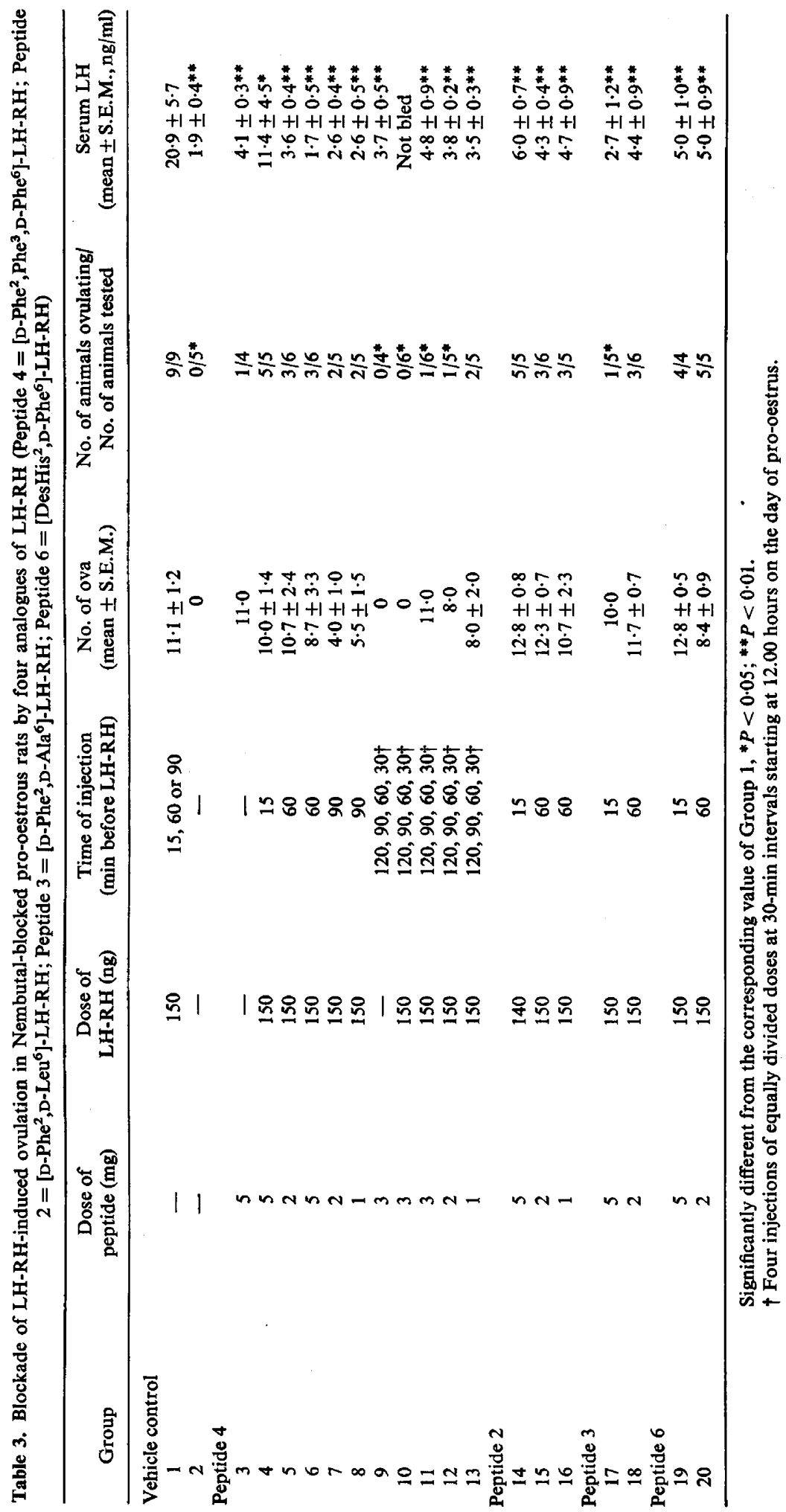


At a single dose of $400 \mu \mathrm{g}$, Peptides 1, 2 and 5 exhibited considerable intrinsic activity (Table 2). Corbin \& Beattie (1975) also reported that Peptide 3 possessed agonistic as well as antagonistic activity, but the agonistic activity was not strong enough to induce ovulation in Nembutal-blocked pro-oestrous rats, even when the i.v. dose was as high as $100 \mu \mathrm{g}$.

Considerable suppression of serum LH levels was observed after injection of most of the analogues tested (Table 3), but dose-response relationships appeared to be of the 'all-or-none' type. It appeared to be necessary to lower $\mathrm{LH}$ levels to $5 \mathrm{ng} / \mathrm{ml}$ to suppress ovulation: when $\mathrm{LH}$ levels were above $5 \mathrm{ng} / \mathrm{ml}$ ovulation occurred in all the rats. De la Cruz et al. (1976b) suggested that $11 \%$ of the total $\mathrm{LH}$ released during the afternoon of pro-oestrus was sufficient to induce full ovulation in hamsters.

The fact that the ovulation number induced by the intrinsic LH-RH activities of $400 \mu \mathrm{g}$ Peptides 1,2 or 5 appeared to be similar to or greater than those resulting from combined administration of $150 \mathrm{ng} \mathrm{LH}-\mathrm{RH}$ plus one of these analogues (Table 2), indicates that the ovulatory activity of LH-RH itself was eliminated by pretreatment with the analogues.

We thank Mrs J. Gauthier and Mrs D. Pierson for their technical help; Dr A. J. Kastin and Ms G. Farley for their help in preparing the manuscript; Dr M. Fujino, Takeda Chemical Industries for LH-RH; and Dr G. D. Niswender and NIAMDD Rat Pituitary Hormone Program for the radioimmunoassay reagents. The work was supported in part by NIH Contract NICHD-72-2741, NIH research grants HD-06555 and AM-07467, and the Veterans Administration.

\section{References}

CORBIN, A. \& Beattie, C.D. (1975) Inhibiting of the preovulatory proestrous gonadotropin surge, ovulation, pregnancy with a peptide analogue of luteinizing hormone releasing hormone. Endocrine Res. Commun. 2, 1-23.

Coy, D.H., Vilchez-Martinez, J.A., CoY, E.J., Arimura, A. \& Schally, A.V. (1973) A peptide inhibitor of luteinizing hormone-releasing hormone (LH-RH). J. clin. Endocr. Metab. 37, 331-333.

Coy, D.H., CoY, E.J., Schally, A.V., VilchezMartinez, J.A., Debeljuk, L., Carter, W.H. \& ARIMURA, A. (1974) Stimulatory and inhibitory analogs of luteinizing hormone releasing hormone. Biochemistry, N.Y. 13, 323-326.

de la Cruz, A., Coy, D.H., Schally, A.V., Coy, E.J., de la Cruz, K.G. \& Arimura, A. (1975) Blockade of the preovulatory LH surge in hamsters by an inhibitory analog of LHRH. Proc. Soc. exp. Biol. Med. 149, 576-579.

de la Cruz, A., CoY, D.H., Vilchez-Martinez, J.A., ARImura, A. \& Schally, A.V. (1976a) Blockade of ovulation in rats by inhibitory analogues of luteinizing hormone-releasing hormone. Science, N.Y. 191, 195-197.

de la Cruz, A., Arimura, A., de la Cruz, K.G. \& SCHALLY, A.V. (1976b) Administration of antiLHRH serum on gonadal function during the estrous cycle in the hamster. Endocrinology 98, 490497.

Duddleson, W.G., Midgley, A.R., JR \& Niswender, G.D. (1972) Computer program sequence for analyses and summary of radioimmunoassay data. Computers \& Biomed. Res. 5, 205-217.

Evrretr, J.W. (1974) Preoptic stimulative lesions and ovulation in the rat: "thresholds" and LH-release time in late diestrus and proestrus. In Major Problems in Neuroendocrinology, pp. 346-366. Eds D. Bajusz \& G. Jasmin. S. Karger, Basel.

Hsu, T. \& Feldr, L. S. (1969) The effect of limitation on the number of criterion score values on the significance level of the F-test. Am Ed. Res. Jl 6, 515-527.

Niswender, G.D., Midgley, A.R., JR, Monroe, S.E. \& REICHERT, L. E., JR (1968) Radioimmunoassay for rat luteinizing hormone with anti-ovine $\mathrm{LH}$ serum and ovine LH-1311. Proc. Soc. exp. Biol. Med. 128, 807-811.

Seeger, P. \& Gabrielson, A. (1968) Application of the Cochran $O$ test and the F-test for statistical analysis of dichotomous data for dependent samples. Psychol. Bull. 69, 269-277.

Seyler, L.E., JR \& ReIchlin, S. (1973) Luteinizing hormone release in the rat induced by blood volume depletion. Endocrinology 92, 295-302.

STEEL, R.G.D. \& TORRIE, J.H. (1960) Principles and Procedures of Statistics, pp. 114-117. McGraw-Hill, New York.

Vilchez-Martinez, J.A., Schally, A.V., Debeljuk, L., CoY, D.H., CoY, E.J., Arimura, A. \& YanaIHARA, N. (1974a) Development of a method to test anti-LHRH activity in rats. Neuroendocrinology 14, 121-128.

Vilchez-Martinez, J.A., Schally, A.V., CoY, D.H., CoY, E.J., DebelJuK, L. \& ARimura, A. (1974b) In vivo inhibition of LH-release by a synthetic antagonist of LH-releasing hormone (LH-RH). Endocrinology 95, 213-218.

WARD, M.C. (1946) A study of the estrous cycle and the breeding of the golden hamster (Cricetus auratus). Anat. Rec. 94, 139-161. 